\title{
Obrazy integralności sędziowskiej. Wprowadzenie
}

W niniejszym tomie tematycznym „Krytyki Prawa” opublikowane zostały między innymi artykuły inspirowane obradami, jakie miały miejsce podczas konferencji zorganizowanej przez Instytutu Etyki Prawniczej pt. Integralność sędziego i petnomocnika procesowego ${ }^{1}$. Temat ten stanowi, w pewien sposób, kontynuację badań nad podmiotowością i odpowiedzialnością prawnika w świecie instytucji prowadzonych wcześniej w ramach Instytutu ${ }^{2}$.

Jeden z problemów, który wtedy się wyłonił, dotyczył integralności jako: 1) tożsamości, bycia sobą bez względu na ilość wykonywanych ról (czasem konfliktowych) w sferze życia codziennego. W tym ujęciu integralność oznacza umiejętność zachowania autonomii wobec wymogów praktyk społecznych, w których funkcjonujemy; 2) postawy uczciwości rozumianej w szczególny sposób: jako wierność własnym przekonaniom moralnym, która widoczna jest w działaniach danego podmiotu. W tym ujęciu integralność określana jest jako zgodność postaw i czynów, a za jej przeciwieństwo przyjmuje się hipokryzję.

Odwołując się do tych ustaleń, obecnych w debacie o zawodach prawniczych, uznaliśmy, że warto bliżej przyjrzeć się kategorii integralności w odniesieniu przede wszystkim do zawodu sędziego. Przekonanie to wzmacnia prowadzona w Polsce, zwłaszcza w ostatnim czasie, debata wokół roli sędziego w państwie prawa. Sprawia ona, że problematyka integralności sędziego staje się ważnym tematem z powodów nie tylko teoretycznych, lecz także praktycznych. Podjęcie tego tematu można zatem rozumieć jako próbę odpowiedzi na te problemy poprzez ich ekspozycję.

Integralność należy do podstawowych pojęć w debacie o roli sędziego, ale także pełnomocnika procesowego (adwokata, radcy prawnego), co znalazło odzwierciedlenie w tomie. $W$ wymienionych rolach, ważnych z punktu widzenia obsługi prawa jako mechanizmu układania relacji międzyludzkich, mamy do czynienia

1 Konferencja pt. Integralność sędziego i petnomocnika procesowego w dniu 5 marca 2021 r. została zorganizowana przez Instytut Etyki Prawniczej w formie zdalnej.

2 Zobacz teksty w: „Archiwum Filozofii Prawa i Filozofii Społecznej” 2018, nr 1, który jest numerem tematycznym pt. Etyka prawnicza. Działanie prawników w świecie instytucji. 
z podmiotem działającym w strukturach instytucjonalnych. Jednostka, przyjmując na siebie określone role zawodowe, staje przed roszczeniem do akceptacji obowiązku działania zgodnie z celami i regułami danej instytucji. Może jednak pojawiać się sytuacja konfliktu między moralnością instytucjonalną a moralnością indywidualną, a także oczekiwaniami opinii publicznej. O konflikcie możemy również mówić, gdy osoba odgrywa kilka ról, które wymagają sprzecznych ze sobą działań. Im bardziej wyraźne jest zróżnicowanie pomiędzy praktykami społecznymi i ich systemami norm, tym trudniej jest jednostce zintegrować ze sobą różne odgrywane przez nią role. Dodajmy do tego, że wykonywanie profesji często łączy się z niepokojem, napięciem związanym z oczekiwaniami poszczególnych partnerów $\mathrm{w}$ roli. $\mathrm{Z}$ tego powodu ważne staje się zachowanie autonomii i zdolności oceniania własnych działań oraz celów i reguł praktyk społecznych (instytucjonalnych), w których funkcjonujemy.

Działanie jednostki może być oceniane zarówno w świetle spełnienia wymogów instytucjonalnych, własnych przekonań, oczekiwań opinii publicznej czy też uczestników postępowania sądowego. Stosunek tych ocen może być poważnym problemem dla zachowania integralności, zwłaszcza w zawodzie sędziego. Z tego też powodu uczyniliśmy go centralnym tematem niniejszego tomu. Rola sędziego polega na sprawowaniu jednej z władz w państwie konstytucyjnym, co czyni jego integralność kwestią publiczną. Zarówno praktyczne skutki dążenia sędziów do jej zachowania, jaki konsekwencje jej braku, dotyczą bowiem nie tylko ich samych, ale przede wszystkim obywateli. W duchu filozofii Ronalda Dworkina można powiedzieć, że jest to zagadnienie fundamentalne także dla zasad, na których opiera się cała wspólnota polityczna. Chcemy poddać dyskusji zarówno kwestie teoretyczne, jak i praktyczne związane z integralnością sędziowską. W szczególności wyróżnić pragniemy integralność moralną, polityczną i religijną jako aspekty ogólnego jej pojęcia.

Za ważne uważamy zatem m.in. pytania dotyczące wolności wypowiedzi: czy sędziom przysługuje prawo do posługiwania się argumentami moralnymi i politycznymi w interpretacji i stosowaniu prawa? Czy sędziom wolno ujawniać swoje poglądy i krytykować inne władze? Wreszcie, jakie okoliczności mają wpływ na zachowanie sędziowskiej integralności?

Celem niniejszego tomu nie jest przy tym ukazanie jednego wewnętrznie spójnego pod względem metodologicznym i problemowym sposobu ujmowania kwestii integralności. Raczej zakładamy, że mamy w nim do czynienia z ekspozycją obrazów integralności (zwłaszcza) sędziego, na które składają się poszczególne stanowiska i problemy.

Zachęcając do lektury, chcielibyśmy podziękować Redakcji „Krytyki Prawa”, a w szczególności Pani Profesor Jolancie Jabłońskiej-Boncy za zainteresowanie, 
z jakim spotkała się propozycja publikacji numeru tematycznego. Za sprawą życzliwości i pomocy, jaką otrzymaliśmy od całej Redakcji, udało się opublikować prezentowany tom. Było to możliwe także dzięki zaangażowaniu Autorów, którym dziękujemy za udział w konferencji i przesłane teksty, a wszystkim jej uczestnikom za ciekawą dyskusję. Wpływ na ostateczny kształt publikacji, zarówno w wymiarze merytorycznym, jak i organizacyjnym, miały też opinie Recenzentów, którym również składamy podziękowania.

$$
* * *
$$

Kiedy planowaliśmy debatę o integralności sędziego oraz pełnomocnika procesowego, w ramach wspomnianej konferencji, życzyliśmy sobie, żeby uczestniczył w niej Pan Profesor Ryszard Sarkowicz. Jego przedwczesna śmierć spowodowała, że nie udało się tego zamiaru zrealizować. Chcielibyśmy niniejszy tom zadedykować Panu Profesorowi Ryszardowi Sarkowiczowi, którego prace z etyki prawniczej miały wpływ na nasze zainteresowanie problematyką zawodów prawniczych i wciąż są obecne w prowadzonych rozmowach ${ }^{3}$.

Przemysław Kaczmarek, Paweł Skuczyński Wrocław-Warszawa, wrzesień 2021 r.

3 W tym zakresie na szczególne wyróżnienie zasługuje książka Ryszarda Sarkowicza, Amerykańska etyka prawnicza, Zakamycze 2004. 